\title{
Trádler Henrietta
}

\section{A HANKISS-JELENSÉG, AZ EMBERI JELENSÉG}

\author{
DOI 10.35402/kek.2019.3.8
}

\begin{abstract}
Absztrakt
Hogyan összegezhetnénk Hankiss örökségét? Mit hagyott örökül a sokoldalú gondolkodó? Hankiss Elemér a folyton kérdező értelmiségi, az igazi public intellektuel megtestesítője volt. Hankiss munkásságára jellemző a folytonos kísérletezés. A szociológus ki mert lépni a dobozból, mert gondolkodni. Nem rémült meg az új tudományterületektől, amikor válaszokat keresett. Az elmúlt évben két nagy munka tisztelgett a szociológus előtt. A Helikon szerkesztésében megjelent Hankiss Emlékkönyv és a Miszlivetz Ferenc által szerkesztett Magyar Tudomány Hankiss különszáma. A szociológus személyisége és munkássága inspiratívan hatott a különböző tudományterületek kutatóira.
\end{abstract}

\section{Abstract}

How could we sum up the heritage of Elemér Hankiss? What was left behind this multi-talented thinker? He was the embodiment of an intellectuel always in search of truth, in the service of public. His overall work is a through-and-through, neverending experiment. The sociologist was brave enough to step out of his box, and to think. When looking for was answers, he was not scared by the new branches of science. Last year two great work paid homage to the genial sociologist - the Hankiss Emlékkönyv published by Helikon, and a Hankiss supplement of the Magyar Tudomány edited by Ferenc Miszlivetz. The personality and oeuvre of the great sociologist had an inspiring effect on the researchers of various fields of science.

Még történész-hallgató diákként azt a tanítást kaptam: amikor kutatok, mindig legyen egy jó, releváns kérdésem. Hankiss írásai arra tanítanak, hogy merjek kérdezni, és sok kérdést tegyek fel arról a problémáról, amivel foglalkozom. A válasz korántsem evidens, sőt nem feltétlenül létezik egyetlen érvényes és helyes válasz, egyszerre többféle megoldás is elfogadható lehet. Mára klasszikusnak számít Natalie Zemon Davis Martin Guerre visszatérése című mikrotörténeti munkája, ahol hőseit dön- tésképes, cselekvő emberekként ábrázolja, ráadásul úgy, hogy bemutatja az egyes döntési alternatívákat. Hankiss Emberi kalandjában is hasonló gondolatok jelennek meg - úgy vélem, a történész hallgatóknak Natalie Zemon Davis mellett több Hankisst is kellene olvasniuk annak érdekében, hogy releváns kérdéseket tudjanak feltenni és többféle választ is képesek legyenek megfogalmazni.

Hankiss Elemért nem ismertem személyesen. A 2014-es kőszegi nyári egyetemen meghallgathattam egy előadását, de soha nem nyílt alkalmam négyszemközti beszélgetésre. Mégis, az idősebb kollégák részletes beszámolói alapján folytonosan kérdező értelmiséginek látom, aki sok oktató és kutató társával ellentétben kíváncsi volt a kérdéseire kapott válaszokra (is). Írásait olvasva klasszikus értelemben vett public intellectual volt, vagyis vállalta, hogy érthetően és nagy közönséghez szól. Kísérletezett, nem rémült meg az új tudományterületektől, amikor válaszokat keresett. Ki mert lépni a „dobozból”, $s$ mert paradigmát váltani, másképp gondolkodni. Az akadémiai értelmiség nem fogadta be egyöntetüen, ellenben az átfogó témák iránt érdeklődő publikum annál jobban magáénak érezte szemléletét. Hankiss tágította, átlépte a tudományok közötti határokat, könnyedén és elegánsan közlekedett az egyes diszciplínák között, ahogyan ő fogalmazott „oszcillált”. ${ }^{1}$ Sokan nem értették, míg mások csodálattal nézték a működését. Hankisst valójában a legfontosabb filozófiai problémák, a lét és a nemlét, az értelmetlenség és értelem különbsége érdekelték, ezekről a fogalmakról gondolkodott a legtöbbet. ${ }^{2}$ Irodalmárként kezdte pályafutását, és public intellectualként fejezte be. ${ }^{3}$

1 Miszlivetz Ferenc: Tudományon innen és túl. Magyar Tudomány, Hankiss különszám, 2018/10:1435-1439.

2 Miszlivetz uo. 1435-1437. http://dx.doi. org/10.1556/2065.179.2018.10.1

3 Csepeli György: Egy 21. századi tudós a 20. században - Hankiss Elemér életei. Magyar Tudomány, Hankiss különszám 2018/10:1466-1470 - http:// dx.doi.org/10.1556/2065.179.2018.10.5 ; Mátay Mónika: A múlt csapdái a jelenben. $M T$ uo. 14881492 http://dx.doi.org/10.1556/2065.179.2018.10.7 ; Miszlivetz uo. 
Miért fontos megértenünk Hankiss Elemér tudósi-emberi gyökereit? A Debreceni Egyetemen, ahogyan ő mondja, a Tündérkertben nőtt fel, abban a korban, amikor Klebelsberg Kuno politikájának köszönhetően a két világháború között pártolták a magyar kultúrát, fejlesztették a hazai egyetemeket, többek között a Debreceni Egyetemet is, ahol Hankiss János irodalmár tanított és élt a családjával. Hankiss a két háború közötti időszakra jellemző középosztályi, értelmiségi nevelést kapott, amely meghatározta egész pályafutását. A német megszállás, holokauszt, világháborús vereség, orosz megszállás szétzilálták a gyerekkor boldog világát, a trauma az élete végéig elkísérte. Az értelmiségiek közül sokan külföldre menekültek, sokan itthon maradtak és beilleszkedtek, alkalmazkodtak az új politikai rendszerhez. Megint mások perifériára szorultak, megtűrtekké, tiltottakká váltak. Hankiss itthon maradt és ez utóbbi utat választotta. ${ }^{4}$ Ezen a bizonytalan, sokszor homályos úton járva alakította a pályáját közel negyven éven keresztül, a rendszerváltásig, majd jutott még szűk negyedszázad, amikor szabadon gondolkodhatott és írhatott.

A Hankiss-életműről két áttekintés látott napvilágot a közelmúltban. A kőszegi Felsőbbfokú Tanulmányok Intézete (iASK) két és fél évvel a halála után, 2017. június 8-9.-én Hankiss Elemér tiszteletére nemzetközi emlékkonferenciát rendezett. A konferencián számos külföldi és magyar előadó jelent meg, előadásaik írott változatait a Miszlivetz Ferenc által szerkesztett Magyar Tudomány Hankiss különszáma (2018) tartalmazza. A kötetnyi anyag célja Hankiss tudományos eredményeinek, szellemi hagyatékának, és inspiráló képességének bemutatása, amihez több tudományterület kutatói járultak hozzá tanulmányaikkal. A szövegeket sikerült az életpályát tükröző gondolatmenetre felfüzni, a személyes hangvételü írásoktól nyomon követhető az irodalmár, majd szociológus Hankiss, később a korát megelőző, töprengő tudós, akinek felvetéseit a mikrotörténészek és a Big History irányzat művelői is figyelemre méltónak tartják. Ezután olvashatóak a bizonytalanság koráról szóló tanulmányok, majd a biológusok, fizikusok dolgozatai. A kötet kuriózuma, hogy poszthumusz Hankiss esszét közöl magyarul $A$ kvantummechanika és az élet értelme címmel, amelyre Kroó Norbert, fizikus reflektál (10:1572-1579).

Ugyancsak 2018-ban a Helikon Kiadó gondozásában, Takács M. József szerkesztésével megjelent

4 Csepeli György uo. egy Hankiss-emlékkötet. Az utóbbi műfajában eltér a Magyar Tudománytól, míg a Hankiss különszám tematikus szerkesztett, tudományos dolgozatokat közöl, a Hankiss Emlékkönyvbe Hankiss családtagjai, barátai, munkatársai jegyeztek rövidebbhosszabb, személyesebb hangvételü, szubjektív emlékekre épülő szövegeket. Mindkét válogatás célja a Hankiss Elemér munkássága előtti tisztelgés, de műfajából adódóan a két kiadvány más olvasóközönséghez szól, másféle írásokat közöl, az egyikben a tudóst, a másikban inkább az embert láttatják a szerkesztők - már amennyiben a kettő szétválasztható és szétválasztandó. Valamelyest igen, ezt mutatja a két válogatás.

A Hankiss-Emlékkötet sokféle írást tartalmaz közel 30 szerző tollából, amelyeket Takács M. József öt nagyobb témakörbe szerkesztett. Az első fejezet, az Emlékezések családtagok, közeli barátok visszaemlékezéseit tartalmazzák, a második, a Tanulmányok Hankiss-ról, illetve a Hankiss által inspirált, tudományos igényességgel megírt munkákról szólnak. A harmadik fejezet a kőszegi műhely tevékenységét mutatja be, a negyedik fejezet a korábban megjelent, Hankissal készített interjúkból, míg az ötödik, egyben utolsó fejezet az életút fontos dokumentumaiból közöl válogatást. Az előszót Takács M. József jegyzi, az utószót pedig az özvegy, Zétényi Lili személyes, már-már intimnek mondható írása zárja, ahol a szerző bepillantást enged privát, családi életükbe. A kötet válogatott fényképgyüjteményt is tartalmaz, ami lehetővé teszi az olvasó számára, hogy még plasztikusabb képet alkothasson Hankissról.

A két kötetnyi anyag szerzői között van átfedés, ami nem véletlen, hiszen mindnyájan Hankiss kollégái, barátai, követői voltak. Írásomban a Hankiss által felvetett problémaköröket tárgyaló tanulmányokat mutatom be.

Hankiss Elemér pályájának megértésében Bokányi Péter és Csepeli György kalauzolja az olvasót már csak azért is, mert Hankisst irodalmárként és szociológusként ismerik a leginkább a tudományos életben. A tanulmányok kontextusba helyezik a gondolkodót és az életművét. Az irodalmár Bokányi Péter $N e$ hadarj! címü írásában elemzi Hankiss János, az apa és Hankiss Elemér, a fiú életútjában párhuzamos eseményeket. Az irodalomtörténész apa pályája sok szempontból hasonlóságok fedezhetőek fel. Hankiss János klasszikus értelmiségi a Horthy-kori Magyarországon. Olvasott, tájékozott, több nyelven beszélő értelmiségi, aki Nyugaton, 
Genfben és Párizsban végzi egyetemi tanulmányait, majd az első világháború után a Debreceni Egyetemen marad megbízott egyetemi tanárként. Később pályát módosít, zenetörténettel kezd foglalkozni. ${ }^{5}$

Fia, Elemér, és a két nagyobb testvér, pezsgő szellemi légkörben, középosztályi közegben nőnek fel, az édesapa mintakép a számukra. Amikor Hankiss 1993-ban lemond a Magyar Televízió elnöki posztjáról, boldog, hogy újra szakmájának élhet. Hankiss Elemér az élete végén visszatért az irodalomhoz, az ő eredeti szakmájához. „Ne hadarj” - üzente Hankiss János Budapesten tanuló fiának - vagyis beszélj érthetően. Hankiss megfogadta apja tanácsát, az írásaiban mindenképp. Bokányi szerint Hankiss egy új, értekező nyelveszményt honosított meg a magyar irodalomtudományban: tüpontos, sallangoktól mentes hang volt az övé. Nagy hibát követünk el, ha azt vizsgáljuk, hogy mely tudományterületen milyen eredményeket ért el Hankiss. Életműve abban igazán egyedülálló, hogy a diszciplínák között mozgott, egyiket összekötötte a másikkal, életmüvében a gondolatsor számít. ${ }^{6}$

Hankiss szellemiségének kulcsát Csepeli György Egy 21. századi tudós a 20. században címü szövegéből érthetjük meg. Hankiss (családja miatt) az 1950-es években nem juthatott képzettségének megfelelő szerephez. Dolgozott „multinál”, a Ferunion külkereskedelmi vállalatnál, majd az Országos Széchenyi Könyvtárban. A forradalom után visszavették a könyvtárba, majd az MTA Irodalomtudományi Intézetében helyezkedett el. Hankiss irodalomtól való eltávolodását 1977-ben megjelent kötete vetítette előre, amely már a társadalomhoz való közeledését jelzi. Az értékvizsgálati kutatások során Hankiss szociológus énje bontakozott ki. Csepeli szerint Hankiss a modern, álmodó értelmiségiek archetípusa. A korabeli szociológiai trendek szerint a 20. század legfóbb problémája az elmaradottság kérdése, az ekkor született munkák az egyenlőség hiányát mutatták be az élet különböző területein. ${ }^{7}$

Hankiss meghatározó szociológiai témájú müvei is az 1970-80-as években láttak napvilágot. A hatalom ekkoriban már nem üldözte a szociológiát abban az értelemben, hogy a diszciplína kiléphetett a „burzsoá áltudomány” skatulyából, de az Aczél-i kultúrpolitika szigorúan ellenőrizte a szociológu-

5 Bokányi Péter: „Ne hadarj!”. MT 10:1457-1461. http://dx.doi.org/10.1556/2065.179.2018.10.4

6 Bokányi uo. 1461-1464.

7 Csepeli uo. 1465-1477. sok munkálkodását. Hankiss édesapja révén tudta, hogy a tudományos élet nélkülözhetetlen előfeltétele a nemzetköziség, a külföldi szakmai beágyazottság. Értékkutatási elemzései kapcsán összehasonlító vizsgálatokat végzett, más országok értékkutatási eredményeit vetette egybe a magyarországi értékekkel, így eleget tett a „nemzetköziség” kritériumának. Csepeli szerint a „hankissi jelenség” abban rejlik, hogy kilépett a hagyományos akadémiai keretek világából. Ezzel párhuzamosan hatást gyakorolt a közvéleményre, hiszen közérthetően írt. A dilemma kifejezés helyett például a hétköznapi értelemben is használt csapdát alkalmazta, így az olvasók könnyedén megérthették mondanivalóját. Hatása - Csepeli szerint -, hogy közgazdasági, szociológiai és társadalomtudományos fogalmak használata helyett közérthetően írt le társadalmi jelenségeket. ${ }^{8}$

A társadalmi csapdák kérdéskörét boncolgatja Schöpflin György, politológus, az Európai Parlament képviselöje is. Schöpflin a társadalmi csapdákat a Bibó-i zsákutcához hasonlítja, majd kifejti, hogy Nyugat- és Közép-Európa kapcsolatát „aporetikus” jellegű hatalmi viszonyok hálójaként értelmezhetjük. A szerző Európa két részét állítja szembe egymással. Úgy véli, a kontinens keleti felén másként értelmezték a közpolgáriságot (citizenship), a nyugat-európai kritériumokhoz képest gyengébbnek tekintették. A cselekvőképesség problémáját nem orvosolták, az értelmiségi, kognitív elitek a kommunizmus idején biztos pozícióhoz jutottak, amelyeket bizonyos mértékig a rendszer konstruált. Ez az új osztály bebetonozta magát, hatalmát sikeresen tovább örökítette. Gátolták a felfelé irányuló társadalmi mobilitást, ennek az lett az eredménye, hogy társadalmi zárványok alakultak ki, élükön a hegemonikus elittel. A kommunizmus összeomlásakor ez az önjelölt elit tovább örökítette magát, képviselői liberálisként, demokratikus szocialistaként jelentek meg az új rendszerben. A Nyugat elfogadta ezt a felállást, az ex-kommunista elit ily módon sikerrel folytathatta a korábbi társadalmi kirekesztést. Hosszan lehetne sorolni a társadalmi csapdákat a Nyugat és a Kelet között, idetartozik Schöpflin szerint - a közép-kelet-európai államok téves várakozása az Európai Unióba való beléptetésére, a Nyugat és Kelet kölcsönös értetlensége egymás iránt, egymás nem ismerése, az idealizálás, és a másik fél leértékelése, lenézése. A szerző bemutatja Közép-Európa hamis narratíváit, azt a törté-

8 Csepeli uo. és Csepeli György: Hankiss Elemér és a magyar szociológia. In Hankiss-Emlékkönyv. Helikon, 2018:157-168. 
neti fejlődést, miszerint a hatalmi aszimmetriákat, Nyugat- és Kelet-Európa különböző konfliktuskezelési módszereit. Közép-Európa a 2004-07-es bővítés során arra várt, hogy valóban csatlakozhat Európához. A tizenöt uniós tagállam úgy gondolta, hogy Közép-Európa integrálható Nyugat-Európába. Schöpflin úgy véli, ez volt a csapda akkor is, és most is ez. ${ }^{9}$

A megnemértettség, a téves elvárások, konfliktusok bizonytalanságot szülnek. A válság, bizonytalanság Hankiss világának visszatérő, központi témája. Nem véletlenül. A gazdasági válság hatása a történetírásban is erőteljesen érzékelhető. A 20 . század végére a nyugati történészek elveszítették a kapitalizmus története iránti érdeklődésüket, ami a 2008-as világválság következtében ismét meghatározó kutatási témává vált. 2008-at követően világszerte válságkutató csoportok, tanszékek, kutatási projektek alakultak, amelyekben a krízis előzményeit, okait, következményeit kutatták. A probléma szerves része a bizonytalanság megjelenése az élet különféle területein. A világ vezető egyetemei, többek között a Harvard Egyetem, létrehozta a „The Study of Capitalism”, a Cornell a „History of Capitalism” központot, ahol az amerikai kapitalizmus történetét vizsgálják. A kutatók az amerikai kapitalizmus vállalkozástörténetére, elhibázott gyáralapításaira, a gyári munkások és az újonnan érkezett gazdasági migránsok módszeres vizsgálatára vállalkoztak. Az elemzés a történettudomány számos területére - munka, kultúra, gender, állam, gazdaság és környezetvédelem - kiterjed. Az egyetemek célja egyértelmüen a kapitalista fejlődés szerteágazó diskurzusának kutatása lett, amihez szemináriumokat, konferenciákat, nyári egyetemeket szerveznek. A világválságot követő bizonytalan gazdasági légkörben több meghatározó munka is született. ${ }^{10}$

A bizonytalanság korát éljük, ez a bizonytalanság az élet minden területén megjelenik, a tudo-

9 Schöpflin György: Közép-Európa és az európai „társadalmi csapda” - az EU-terápia kudarca KözépEurópában. In Hankiss-Emlékkönyv. Helikon, 2018:230251.

10 lásd bővebben: Jürgen Kocka The Short History of Capitalism. 2016; Neal D. Larry: The Cambridge History of Capitalism. Cambridge University Press, Cambridge (Mass.), 2014; Alexander Anievas - Kerem Nisancioglu: How West Came to Rule: The Geopolitical Origins of Capitalism. Pluto Press, London, 2015; Amiya Kumar Bagchi: Mankind and the Global Ascendancy of Capital. Rowman and Littlefield Publishers, Lanham, 2006; Sven Beckert: Empire of Cotton: A Global History. Knopf, New York, 2014 mányban, és az én-válságban is. Jody Jensen, iASK kutató vizsgálatát is Hankiss Elemér inspirálta. Jensen állítása szerint a Hankissal történt egyik beszélgetése során hallott először az axiális korokról, amikor az emberi gondolkodásnak és a cselekvésnek a múltban lezajlott paradigmaváltásai újra bekövetkeznek. Minden paradigmaváltás egy válságos, krízisekkel teli időszakot előz meg. Jensen véleménye szerint a dogmatikussá vált feltevések hátráltatják a tudomány fejlődését, az egyik ilyen feltevés szerint a tudomány már minden kérdésére megtalálta a megfelelő választ és csupán a részleteket kell kidolgozni. A világról alkotott ismereteink folyamatosan alakulnak, a tudás átadásának és szemléletének módja ellenben nem változik. A tudomány és a társadalom között egyre mélyebb szakadék tátong, mivel a mai tudományos diskurzus túlságosan szakosodott, szétaprózódott. A tudás bizonyos diszciplínákban váratlanul jön létre és változik meg egyik napról a másikra, más területeken pedig több évszázad is eltelhet, mire a paradigmaváltás megtörténik. A tudományban irreálisan nagy szerepet tölt be a validálás, amely kvantitatív statisztikai adatsorok elemzése során történik meg, ezzel olyan tényezőket zárnak ki az elemzésből, amelyek meghatározóak lehetnek az elemzés során. Ez a folyamat játszódik le számos társadalmi kérdés és kihívás során, a jelenlegi migrációs válság és terrorizmus esetében is. A paradigmák újraértelmezése sokszor csak akkor történik meg, amikor generációváltásra kerül sor. A sztenderdekhez való alkalmazkodás számos esetben cselekvésképtelenséget idéz elő, például a kormányzati és vállalatvezetési struktúrában, a demokrácia gyakorlatában. Ez a folyamat csak bonyolódik, mivel a kutatások számtalanszor összefonódnak azokkal az aktuális hatalmi elvárásokkal és struktúrákkal, ahonnan az anyagi finanszírozásukat kapják. ${ }^{11}$

Jensen szerint a jelen kor válságait az elmúlt 300 évben uralkodó mechanisztikus világkép, vagyis a világot gépezetként felfogó szemlélet köti össze. Ez alapján mind árucikkek vagyunk, így a tökéletes működés leköti a „gépkezelőt”, az élet értelmetlenné válik. Felül kell emelkedni a mechanisztikus dilemmán. A válságot megerősíti, hogy a kapitalista multinacionális vállalatok - hatalmuk fenntartása érdekében - szövetségesre találnak a nacionalista államok kormányaiban. Ebből kifolyólag sztrájkok, tüntetések zajlanak világszerte a gazdag hatalmi elit ellen. A különböző „gyámkodó intézmények”

11 Jensen, Jody: A társadalomtudományok új szerepe a komplexitás korában. In Hankiss-Emlékkönyv. Helikon, 2018:169-202. 
(WTO; IMF; EU) beavatkozása csak elmélyíti a problémákat. Jensen szerint változás csak akkor következhet be, ha új paradigmatikus megközelítés jön létre, amelynek alapja a holisztikus megközelítés.

Jensen a tudományos paradigmaváltást sürgetni, miszerint a humántudományok és a természettudományok nem egymás ellenségei, sőt valójában egy közös ellenségük van, az oktatási rendszer, amely az elavult struktúrákat támogatja, és nem képez fiatal, kritikus gondolkodókat. A mai kutatóknak arra kellene törekedniük, hogy a tudományterületeket összekössék, és transzdiszciplináris módszertant hozzanak létre. ${ }^{12}$

Az elavult oktatási rendszer részben a tudományok válságához köthető, Igor Stipic és Dimitar Nikolovski, fiatal szociológusok munkáiban egyaránt megjelenik az oktatás válsága és a kritikus gondolkodók kinevelésének mellőzése. Az egyetemek jövőjétől a jövő egyeteméig című tanulmányban a két fiatal tudós a megnövekedett hallgatói tüntetésekből vezeti le érvelését, amellyel eljutnak a jövő egyeteméig. Véleményük szerint a Bolognairendszer bevezetésével járó változások kapcsán tüntetések, petíciók, tiltakozások különböző formái jelentek meg Európa-szerte. A legkedvezőtlenebb tényező - állítják a szerzők - a neoliberális paradigma, vagyis az oktatás elértéktelenedik, a hallgatóra csupán mint olcsó munkaerőre tekintenek az egyetemek, a tudás eszközzé válik, az oktatás szerepe pedig kimerül abban, hogy kitermeli a gazdaságban versenyképes munkaerőt. Az oktatás kvázi piacként jelenik meg ebben a modellben, ahol az egyetemi rektorok, dékánok státuszra és rangra játszanak, úgy, mint a sport világában a futballmenedzserek. A kritikai gondolkodásnál fontosabbá válik a pénz. A diákok a tudás helyett diplomát vásárolnak, egyetemi élményt, az universitasok pedig ezzel bevételüket növelik. Európa nagy egyetemei úgymond „megmarketingelik” magukat, a minél több diák, annál több pénz elvét követik. Céljuk egyértelmű, a piac szereplőivé akarnak válni. Ebből következően az oktatás válságába került, az egyetemek nem kritikus gondolkodókat nevelnek, hanem a hiszékenységet favorizálják. Ez a válság Európa-szerte társadalmi, politikai feszültségekkel jár együtt. Hankiss ezt az állapotot nevezte a bizonytalanság korának. Különbséget kell tenni információ és tudás között, az információ=tényközvetítés, a tudás komplex, valódi megértést jelent. A 21. századi egyetem már nem

12 Jensen uo., valamint A Hankissizmus dialektikája. MT, 10:1524-1529. ilyen - a fiatal kutatók szerint. A jövő egyeteme politikától mentes, kritikus kutatókat nevelő intézmény, ahol saját regionális és releváns nézeteket tanítanak. Mindemellett az oktatás-kutatás-hallgató kapcsolat kiépítése is kulcsfontosságú. ${ }^{13}$

A szociológus Vitányi Iván szerint is az átmenet korát éljük, amelynek egyik fö vonása a bizonytalanság. Hankiss gondolatvilágából kiindulva kezdi érvelését, miszerint két Magyarország-eszme létezik egymással párhuzamosan. Az egyik, amelyet a magyarok sorsán gondolkodó nagy elődök, mások mellett Széchenyi, Kossuth, Ady és Bibó alkottak, de nézeteiket a társadalom egy kisebb rétege értette meg csupán. A másik Magyarországhoz tartozik a feudalizmust őrző többségi társadalom. Hankiss ezért a közgondolkodás megváltoztatásán munkálkodott, ebből a kezdeményezéséből jött létre a „Találjuk ki Magyarországot” mozgalom. Sajnos kevesen értették meg a mozgalom lényegét, amely így nem váltotta be a hozzáfüzött reményeket.

A modernizáció kutatói a glóbuszt fejlettségük szerint különálló régiókra osztották a 20 . században. Ennek értelmében az észak-amerikai és a nyugat-európai térséget centrumokként határozták meg, míg a világ egyéb területei képviselik a félperifériákat és a perifériákat. A múltban úgy tűnt, a bizonytalanság csak a félperifériát jellemzi, mára ez a felfogás radikálisan megváltozott. Jelen világunkban a bizonytalanság hatással van a perifériára is, mely folyamat a világ különböző változásával hozható összefüggésbe. Hankiss érdeme, hogy a nyugati szerzőkkel egy időben fogalmazta meg, hogy a közép-európai régió a bizonytalanság korába lépett, olyan állapotba, amelynek nem ismerjük a folytatását. ${ }^{14}$

Ez a bizonytalanság jelenik meg az én egzisztenciális válságában is. Az amerikai szociológus, James Skelly Hankiss műveiben az én egzisztenciális válságát vizsgálja. Megmutatja, hogyan próbál Hankiss egy olyan víziót felvázolni, amely segítségével az emberek túlléphetnek a létükben rejlő értelemválságokon, amit Hankiss az amerikai terrortámadást követően, 2001. szeptember 11-e után fogalmazott meg egy esszében. Az új fogyasztói civilizáció képtelen választ adni az emberi lét lényegi kérdéseire, a reklámvilág csak felszínes alternatívákat kínál, melyekre

13 Igor Stipic - Dimitar Nikolovski: Az egyetemek jövőjétől a „Jövő Egyeteméig”. In Hankiss-Emlékkönyv. Helikon, 2018:251-264.

14 Vitányi Iván: Hankiss Elemér emlékére. $M T$ 10:1446-1449. http://dx.doi. org/10.1556/2065.179.2018.10.2 
az emberek mindaddig vevők, amíg az állam, vagy más intézmények nem kínálnak alternatívát a számukra. Hankiss írása kapcsán lehet beszélni arról, hogy a halál tagadása a nyugati fogyasztói civilizáció egyik fö jellemzője, mely tényhez szorosan kötődik a klasszikus hadviselés megváltozása. A 21. századi háborúkban, a terrortámadásokban a civil társadalom az ellenség, így elsősorban civilek válnak áldozatokká, és nem katonák. Vagyis, a civilek halála nem pusztán a háború mellékterméke, hanem a célja. ${ }^{15}$

Hankiss Elemér gondolkodásmódja meghaladta a korát. Ugyan nem volt történész, de amint sok élenjáró, történeti kérdéseket is felvetett. Mátay Mónika írásában fejtegeti Hankiss történeti jellegü kérdéseit. Mátay szövegéből megtudhatjuk, hogy Hankiss Elemér a történész Makkai Lászlóval közösen jegyzett Anglia az újkor küszöbén címü kötete az angol reneszánszt és a polgári forradalmat tárgyalja. Ezt a gondolatsort emeli ki Pók Attila történész is. Pók szerint a Hankissnál csaknem 14 évvel idősebb Makkai Lászlót, aki ekkor már nagy tekintélyủ történésznek számított itthon, édesapja révén ismerhette Hankiss. Makkai olvashatta Hankiss Hamlet-esszéit, így esett társszerzőjére a választás. Az Anglia az újkor küszöbén című munkában Hankiss fogalmi keretei illeszkednek a nála idősebb Makkaiéhoz. A történteti munkát követően Hankiss Elemér még egy angol vonatkozású művelődéstörténeti munkát adott közre $A$ régi Anglia hétköznapjai címen, amelyben a Spectator folyóirat írásaiból közölt válogatást. ${ }^{16}$ Mátay szerint Hankiss Diagnózisok címen közreadott népszerű elemzése részben történeti vonalat követ, pontosabban kultúrtörténeti témával kezdődik, ahol a szerző a köszönés természetével foglalkozik. A köszönés - állítja Hankiss - a társadalmi önkép lenyomata. Ha alaposabban szemügyre vesszük a magyarországi köszönési formulákat, világosan érzékelhető a társadalom zavarodottsága. A Horthy-kor alá-fölé rendeletségi rendszere keveredik az egyenlőségi elvekre épülő új társadalomban. Ez a jelenség érzékelhető a mindennapi életben is - olvashatjuk Mátay Mónika tanulmányában. ${ }^{17}$

15 Skelly, James Malachy: Hankiss „fogkréme” ma a jelenkori háború és az én egzisztenciális válsága. $M T$ 10:1515-1523. http://dx.doi.org/10.1556/2065.179.2 018.10 .10

16 Pók Attila: Mit tanulhatnak a történészek Hankissről? MT 10:1507-1514. http://dx.doi. org/10.1556/2065.179.2018.10.9

17 Mátay Mónika: A múlt csapdái a jelenben. $M T$ 10:1487-1498. http://dx.doi. org/10.1556/2065.179.2018.10.7
A mikrotörténeti megközelítés során a kutatásban az egyén, a many people /ordinary people/ vagyis a kisember kerül a vizsgálat fókuszába, a mikroszkóp lencséje alá. A mikrotörténészek szerint a hétköznapi ember maga alakítja az életét, nem pusztán a politikai, gazdasági, társadalmi körülmények foglya-áldozata, hanem aktív cselekvő, a sorsa irányítója. Az egyén viselkedése, önálló cselekvései Hankiss számára is központi kérdésként jelennek meg. ${ }^{18}$

Z. Karvalits László történész a Mátay-féle gondolatmenetet folytatja, tanulmányában is a cselekvő kisember és egy tárgy van a középpontban és persze Hankiss, mint renitens újhistorikus. Z. Karvalits egy porcelán fogpiszkálótartó történetéből kiindulva jut el az újhistorikus Hankissig. A porcelán fogpiszkálótartó egy korábban nagyon sikeres termék egyszerü utánzata, amely az USA-ban terjedt el. Az 1894-es amerikai tarifatörvénynek köszönhetően olcsóbb lett a díszített porcelán tárgyak importja. Egy egyszerű, hétköznapi tárgyat vizsgálva emberi sorsokhoz jutunk el, a jelentős, átfogó változások visszavezethetőek egy-egy kisebb eseményhez, amelyek nagyszabású folyamatokat indítanak el. Az újhistorikus egyik kezével ad, a másikkal elvesz állítja Z. Karvalits. Mit jelent ez? Az újhistorikus bizonyos dolgokat, eseményeket, embereket kiemel a homályból, másokat veszni hagy, Hankiss, mint született újhistorikus válogat az állítások sokaságából. ${ }^{19}$

A Mátay-féle gondolathoz visszatérve, Hankiss a mikrotörténeti kiindulóponttól, szemlélettel jut el a makro szintig, sőt a Big History megközelítésig (David Christian fogalom-képzetéig). Hankiss $A z$ emberi kaland megírása során tudatosan lép ki a dobozból, s vet fel az emberiségre vonatkozó, alapvető kérdéseket. Úgy, ahogyan teszi ezt a közelmúltban világhírűvé vált izraeli történész, Yuval Harari, az egykor középkori hadtörténelemmel foglalkozó kutató, aki eredeti kutatási témájától a Big History műfaja felé fordult. Harari szerint az ember a túlélés érdekében kultúrát hozott létre, Hankiss ezzel párhuzamosan azt állítja, hogy az emberek szimbólumokkal, vagyis védőpajzsokkal vették körbe magukat. A védőpajzs nélkül az emberek nem tudtak volna életben maradni szellemi, testi értelemben. Harari és Hankiss esetében két intellektuális ka-

18 Mátay uo., 1490-1492.

19 Z. Karvalits László: Hankiss Elemér mint renitens újhistorikus. $M T$ 10:1499-1506. http://dx.doi. org/10.1556/2065.179.2018.10.8 
landorról beszélhetünk - mondja Mátay. ${ }^{20}$ Számos történész elrugaszkodik a szigorú értelemben vett történeti diszciplínától, ami a vizsgálódás fókuszát túlságosan leszűkíti. A társadalomtörténész szerint Hankiss Az emberi kalanddal egy olyan „klubhoz” tartozott, ahol tudományok közötti határokat átlépve közlekednek a tudósok, a diskurzus nem egy szűk szakmai közegben folyik, hanem interdiszciplináris keretek között.

A Yuval Harari és Hankiss Elemér munkásságában kimutatható párhuzam más tudományterületet képviselő kutatóknak is szemet szúrt. A fizikus Boda Dezső Mátay Mónikához hasonlóan elgondolkozott a Hankiss Elemér $A z$ emberi kaland (1997) és Yuval Harari Homo Deus (2015) címü könyvében felmerülő párhuzamokon. Mindkét gondolkozó az emberi civilizáció, a kultúra kialakulását boncolgatja munkájában. Az ember úgy jelenik meg a szerzőknél, mint a változásokat befolyásoló, cselekvő résztvevő. Létezhet-e olyan olvasat, ahol az ember kevésbé alakító, sokkal inkább a változások passzív elszenvedője? - teszi fel a kérdést Boda. Az emberiség körülvette magát hiedelmek és rituálék, mítoszok és vallások, filozófiák, erkölcsi normák és műalkotások szféráival, amelyeket együttesen nooszféráknak neveznek. Ezt azért tette, hogy megvédje magát a veszélyekkel és félelmekkel szemben, amelyekkel egy idegen világban meg kellett küzdenie - idézi Boda Hankisst.

Hankiss munkájának központi motívuma a félelem. Harari már túllépett a szorongó értelmiségi Hankiss-féle álláspontján - állítja Boda. A mai kor gyermeke projektekről, agendákról beszél, funkcionális magyarázatai vannak, amelyek célratörők. A központi motívum a kooperáció. A homo sapiens társas lény, sikere az együttműködésben rejlik. Harari történetei és mítoszai a hankissi nooszférának felelnek meg. Mind a két szerző ugyanarra a következtetésre jut, ugyan eltérő nézőpontból. A tárgyak és intézmények mellett a gondolatok és az emberiség közös tudásának is kiemelt fontosságot tulajdonítanak, az emberek, mint aktív szereplők jelennek meg mindkét tudósnál. ${ }^{21}$

A fizikus Boda kiemeli a homo sapiens kooperációs képességét, a nemzetközileg elismert evolúciós biológus, Szathmáry Eörs tanulmányának központi kérdése is az együttműködés, a játékelméletről és a kooperáció, a win/win helyzet szükségszerüségéről

20 Mátay uo. 1490-1498.

21 Boda Dezső: Hankiss, Harari és a replikátorok. MT 10:1546-1556. http://dx.doi.org/10.1556/2065.17 9.2018.10.14 ír. A biológus gondolatmenetét a Diagnózisok érvelésére füzi fel, az evolúciós játékelmélet sikere nagy változásokat indított el. A játékelmélettel foglalkozó kutatások akkor veszítettek a népszerűségükből, amikor a tudósok ráébredtek arra, hogy az emberi viselkedés nem racionális, még a gazdaságban sem, ezzel szemben „evolúcióban az ágensek viselkedését a természetes szelekció az abszolút racionálisnak tünö irányba hajtja abban az értelemben, hogy legrátermettebb változatok maradnak fenn".

A Homo leszármazási vonal evolúciója is így kezdődik, de nem így végződik - állítja Szathmáry. Mivel valahol „útközben” megjelenik a racionalitástól eltérő, érzelemmel teli viselkedés. A legfontosabb kérdés a miért és hogyan? Az egyik válasz a kulturális evolúció. Mindezek ellenére a kooperációs kutatás az egyik legizgalmasabb terület a tudományterületek közötti együttműködésben. Mivel nincs hely az emberi viselkedés evolúciójának rövid áttekintésére sem, ehelyett Szathmáry a közjó mai képére koncentrál. A biológus egy példával szemlélteti a társadalmi csapdát. Szathmáry példája: $\mathrm{N}$ játékos vagyonából valamennyi értéket betesz a bankba. A betett pénz növekszik, majd a pénzt egyenlően osztják szét a játékosok között. A helyzet csalásra csábít. $\mathrm{N}$ úgy gondolja, hogy fizessen többet a többi játékos, nem fog kiderül, ki csalt, mivel mindenki inkognitóban teszi be a pénzt, de ha mindenki így gondolkodik, akkor senki sem nyer, és a játékosok a társadalmi csapda áldozataivá válnak. Ellenben ha együttműködnek, kooperálnak, mindenki jól jár, win/win helyzet alakul ki. Változtatni kell a szabályokon, hogy az együttmüködés váljon domináns viselkedési formává, vagyis vagy átláthatóvá kell tenni a rendszert, fel kell oldani az inkognitót, vagy szankcionálni kell a csalást (ahogy az adóelkerülőket is megbüntetik). A kutatások szerint legjobban a kettő kombinációja működik. Van más megoldás is, a „közjavakba beadott adományok hozadéka nemlineárisan nö a kooperátokrok számával'. Két stabilis egyensúly van, egyik, amikor a defektorok miatt az együttműködés szinte szerényen alakul, a másik a magas kooperációs szinten létrejövő egyensúlyi helyzet, amit a nem-kooperatív egyensúlytól egy vízválasztó választ el, vagyis a társadalomnak át kell lendülnie a holtponton, s ha átlendült, akkor már ott is marad - érvel Szathmáry. ${ }^{22}$

Mi sem bizonyítja jobban a kooperáció, a winwin helyzet sikerességét, mint az a magyar film-

22 Szathmáry Eörs: Játékelmélet és emberi evolúció. MT 10:1540-1545. http://dx.doi.org/10.1556/2065.17 9.2018 .10 .13 
történeti csemege, amit Hankiss kapcsán CsortosSzabó Sándor producer, filmrendező kínál fel az olvasónak. Kevesen tudják, hogy Hankiss Elemérnek nagy érdeme volt az animációs Oscar-díj megszerzésében 1980-ban. Hankiss ekkoriban a Pannónia Filmstúdió művészeti tanácsának tagja volt, a tanácsnak a stúdió rövid és hosszú távú terveit kellett kidolgoznia. Az úgynevezett Művészeti Tanács egyfajta kulturális cenzúraként működött. Hankiss kiállt Rúfusz Péter $A$ légy című, később Oscar-díjas alkotása mellett, amit a Művészeti Tanács tagjai eleinte fenntartással fogadtak. Az ítészek féltek a politikai áthallástól, kit lehet azonosítani a léggyel, ki kergeti, milyen olvasatokat hordoz és az esetleges „beleolvasás” milyen következményekkel jár. Hankiss próbálta az értelmezést a politikáról más irányba terelni - sikeresen. Érvelése szerint ilyen film még nem készült, ebben igaza volt, hiszen 1981-ben egyetlen háttér-animációs filmet sem gyártottak, még az amerikai stúdiókban sem. ${ }^{23}$

Ehhez kapcsolódóan, rádiózás történeti adalékként szolgál Kondor Katalin írása. Kondor Hankiss rádiós munkáit dolgozta fel, ami vitamüsorokat, diákok számára készített rádióinterjúkat jelent, amelyekben különböző kérdésekre keresték a választ. Hankiss alapvetően erkölcsi nézőpontból közelítette meg az egyes problémákat. Kondor példaként említi az Amerika országútján című műsort, amelynek egyik részében az 1916-ban öngyilkosságba menekülö Jack Londonról esik szó, aki ekkor sikeres, gazdag, boldog ember hírében állt. Hankiss azt vizsgálja, milyen küzdelmek, vívódások sorozata vezetett a tragikus eseményhez, próbálja megérteni a bukás okát. A műsoraiban irodalmi, pszichológiai és társadalomtudományi problémák, válaszok ragadnak a hallgatókra. ${ }^{24}$

Vajon hogyan összegezhetnénk Hankiss szellemi tevékenyégét? Ki volt ö? Folytonosan kérdező ember, válaszokat kereső tudós, diszciplínák között vándorló, örökös kalandor? Az utókorra Hankiss Elemér munkáit, szellemiségét, életszemléletét hagyta örökül. A kőszegi műhelyben ez a szellemiség él tovább. Hankiss Elemér számos vele készített interjúban, az Idegen világban című portréfilmjében is Palo Alto-t deklarálja ideális alkotói élettérnek,

23 Csortos-Szabó Sándor: Hankiss és a rajzfilmek. MT 10:1557-1563. http://dx.doi.org/10.1556/2065.17 9.2018 .10 .15

24 Kondor Katalin: Hankiss Elemér rádiós munkásságáról. MT 10:1564-1571. http://dx.doi.org/1 $0.1556 / 2065.179 .2018 .10 .16$ műhelynek a maga számára. Hankiss Elemérnek és Miszlivetz Ferencnek volt egy közös álma, amely csak Hankiss halála után valósulhatott meg. Köszegen 2014-ben az Új-Közép-Európa ösztöndíjprogram keretein belül létrejött egy kutatóintézet szellemi alapja, amely hazánkban még szokatlan jellegü nemzetközileg sokoldalú megközelítéseket, társadalmilag innovatív fejlesztési projekteket foglal magába. Hankiss Elemér régi álma volt ez, amit Palo Alto-ban is megtapasztalt. Fekete hattyúnak nevezte az ötletet, a későbbi iASK-ot (Institute of Advanced Studies Köszeg), amelynek megalakulását már nem élhette meg. ${ }^{25}$ Köszegen, Zétényi Lili hozzájárulásával létrejött a Hankiss Kutató Archívum, erre a célra az Intézet használatra megkapta a Köszegen található egykori Festetics-Chernel palotát, a Chernel utca 10-et. A Hankiss Archívum anyagát Vecsei Márton rendszerezte, Zétényi Lili engedélyével és segítségével gyűjtötte össze Hankiss solymári otthonában a tudós - elsősorban audiovizuális - hagyatékát. ${ }^{26} \mathrm{Az}$ Archívum célja, hogy a hagyatékot megőrizze és kutathatóvá tegye. Emellett az újonnan alakult intézetben Hankiss másképp is jelen van, az ő szellemiségében megfogalmazott projekteken dolgoznak a kutatók. Ezek közé tartozik a kreatív város, azaz a Kraft, és a történeti vonatkozásokat feltáró Beszélő Házak elemzés. ${ }^{27} \mathrm{Az}$ iASK-ban Hankiss kíváncsisága, kérdezősködése, interdiszciplináris szemlélete tovább él. ${ }^{28}$

25 Miszlivetz Ferenc: A kérdező ember. In HankissEmlékkönyv. Helikon, 2018. 388-419.

26 Vecsei Márton: A Hankiss-hagyaték. In HankissEmlékkönyv. Helikon 2018. 377-387.

27 Mátay Mónika: Hankiss Elemér kőszegi mühelye. Hankiss-Emlékkönyv. Helikon, 2018. 367-377.

28 E cikk egy korábbi változata felkerült a Közös Dolgaink blog weboldalára. 